\title{
Didaktisk modell som stöd för en fyllig behandling av det komplexa riskbegreppet
}

\author{
Jesper Sjöström
}

Malmö universitet och NATDID

Många forskare menar att vårt samhälle kan betecknas som ett risksamhälle. Frågor om risk kopplar till flera olika skolämnen och inte minst till de naturvetenskapliga. En ny forskningsartikel presenterar en didaktisk modell som visar på riskbegreppets komplexitet och som hjälper lärare att behandla det på ett fylligt och mångsidigt sätt i sin undervisning.

Kunskap om risk och riskvärderingar lyfts ofta fram som en viktig del av naturvetenskaplig medborgarbildning (på engelska scientific literacy). Det har stor betydelse vid ställningstaganden i samhällsfrågor med naturvetenskapligt innehåll (SNI). Några exempel på SNI-frågor relaterade till risk är genteknik, kärnkraft, mobiltelefoni, vaccinationer och storskalig användning av syntetiska kemikalier.

Forskaren Linda Schenk vid KTH och hennes kollegor har utifrån en gedigen genomgång av forskningslitteraturen inom nv-didaktik och riskvetenskap konstruerat en didaktisk modell över riskbegreppet [1]. Modellen innehåller sju termer som dels handlar om riskers egenskaper, dels om den samhälleliga kontexten. Den visar på komplexiteten i riskbegreppet genom att visa hur de olika delarna samverkar.

\section{Olika syn på risk}

Det finns många dimensioner av risk och det kan definieras på flera olika sätt, både teknisktnaturvetenskapligt och mer vardagligt, och både kvantitativt och kvalitativt. Med kvantitativt menas att det på något sätt går att sätta siffror på risken, att den går att mäta. Med risk avses här möjligheten för skadliga konsekvenser som skulle kunna uppkomma av framtida och i nuläget okända händelser. Risker kan beskrivas på olika sätt, såsom sannolikheten för en händelse, omfattningen och typen. Ett sätt att matematiskt försöka precisera innebörden av risk är att se det som en funktion av sannolikheten för att en viss händelse inträffar och konsekvenserna om denna inträffar.

Riskbegreppet kopplar till både kunskaper och värderingar och har därför både objektiva och subjektiva komponenter. I begreppets kärna finns alltså den rådande (kunskaps)osäkerheten och vilka konsekvenserna blir om det som det finns en sannolikhet för faktiskt blir verklighet. Konsekvenser kan delvis beskrivas objektivt, men hur man ser på allvaret med en viss konsekvens beror på hur man värderar den i relation till annat. I nyare forskningslitteratur betonas att hur man förstår risk ofta beror på sammanhanget.

\section{Didaktisk modell över det komplexa riskbegreppet}

I artikeln [1] presenterar forskarna en didaktisk modell (se Figur 1) som visar på riskbegreppets komplexitet och som hjälper lärare att behandla det på ett fylligt och mångsidigt sätt i sin undervisning. Generellt ger didaktiska modeller lärare teoretiskt stöd vid planering, design, genomförande, analys och/eller utveckling av undervisning. På olika sätt hjälper de lärare att - före, under och/eller efter undervisningen - reflektera över de didaktiska frågorna [2]. I det här fallet rör 
det sig om en didaktisk modell över den didaktiska vad-frågan, alltså innehåll, aspekter och perspektiv då det gäller risk.

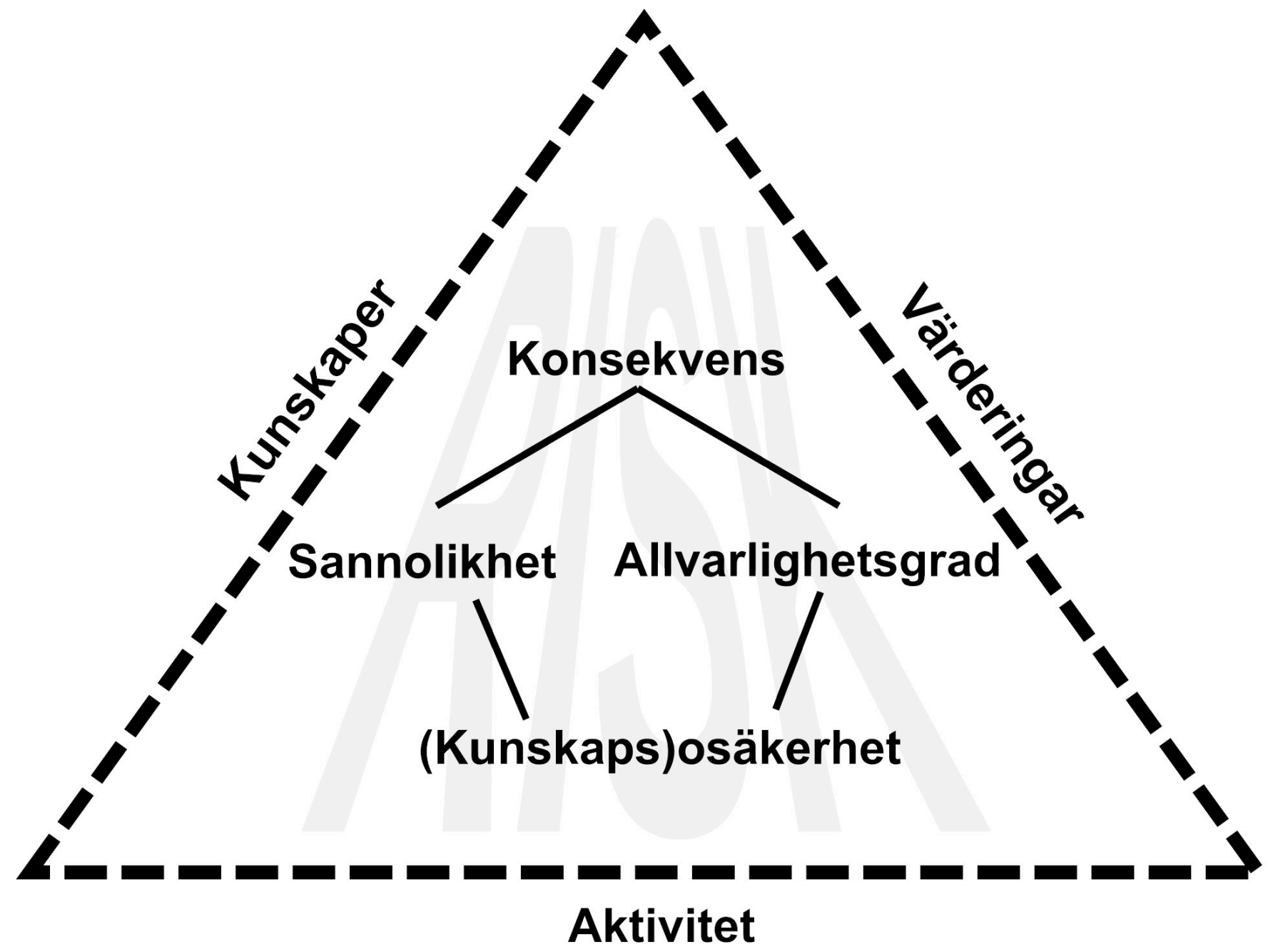

Figur 1. Schematisk framställning av en didaktisk modell av det flerdimensionella riskbegreppet. Modellen är en svensk översättning av modellen i Schenk m.fl. [1].

Som framgår av Figur 1 består den didaktiska modellen av totalt sju termer (här översatta från engelska): (kunskaps)osäkerhet, sannolikhet, allvarlighetsgrad, konsekvens, aktivitet, kunskaper och värderingar.

Den inre figuren med fyra termer ((kunskaps)osäkerhet, sannolikhet, allvarlighetsgrad och konsekvens) är inramad av en triangel där de tre återstående termerna (aktivitet, kunskaper och värderingar) finns på varsin av triangelns sidor. "Aktivitet" finns på triangelns undersida för att fånga uppmärksamhet och betona samspelet mellan risk och handling. Aktivitet står här både för mer övergripande (politiska) aktiviteter såsom att bygga ett nytt kärnkraftverk eller att införa ett nationellt vaccinationsprogram och för handlingar och beslutsfattande mer i det lilla. Det kan exempelvis röra sig om olika beslut i vardagen för att både begränsa riskerna (t.ex. att inte köra för fort) och minska deras allvarlighetsgrad om något skulle inträffa (t.ex. att köra bil med krockkudde).

"Kunskaper" och "värderingar" samspelar då det gäller förståelse och bedömning av risk. Det är viktigt att både kunskaper och värderingar får utrymme i nv-undervisning, även utifrån 
kunskapsteoretiska perspektiv. Genom att arbeta med riskrelaterade samhällsfrågor med naturvetenskapligt innehåll [3] kan man på ett naturligt sätt komma in på frågor kring kunskapsosäkerheter och naturvetenskapens karaktär. Forskarna bakom artikeln pekar på att man explicit bör arbeta med risk i nv-undervisningen och att man genom det indirekt berör även andra centrala delar, såsom frågor kring naturvetenskapens karaktär och arbetsformer.

\section{Modellen kan ge stöd till planering och reflektion}

Den teoretiska didaktiska modellen kring risk togs fram som en del av ett mångvetenskapligt forskningsprojekt kallat RiskEdu1. Projektgruppen består av både forskare från flera olika vetenskapliga fält (riskbedömning, nv-didaktik och strålningsbiologi) och forskande nvgymnasielärare med olika ämneskombinationer. Forskarna studerar, med hjälp av SNI-dilemman i gymnasiets naturvetenskapliga ämnen, modeller för undervisning med fokus på riskbedömningar. Deras nya didaktiska modell syftar alltså till att ge stöd till lärare när de planerar och reflekterar kring undervisning som behandlar risk.

Ett aktuellt exempel på SNI-fråga där modellen kan komma till användning är undervisning kring individuella och samhälleliga överväganden kring covid-19 (Figur 2). Även om kunskaperna växer efterhand finns fortfarande stora kunskapsosäkerheter då det gäller exempelvis smittspridning och egenskaperna hos nya virusmutationer. Genom ett nationellt vaccinationsprogram kommer smittspridningen att minska och de flesta som vaccineras att skyddas mot allvarlig sjukdom. Samtidigt kommer några (ännu oklart hur många) troligen att drabbas av allvarliga biverkningar såsom blodproppar. Den didaktiska modellen av det flerdimensionella riskbegreppet kan hjälpa både lärare och elever att bena ut komplexiteten kring smittspridning och risker för allvarlig sjukdom och biverkningar av vaccinering liksom kring politiska och individuella beslut kring det sistnämnda. Sådana beslut handlar om "aktiviteter" (t.ex. pandemi, nationellt vaccinationsprogram), kunskaper och värderingar och - som modellen illustrerar - hur förståelsen av dessa påverkas av (kunskaps)osäkerhet, sannolikhet, allvarlighetsgrad och konsekvenser.

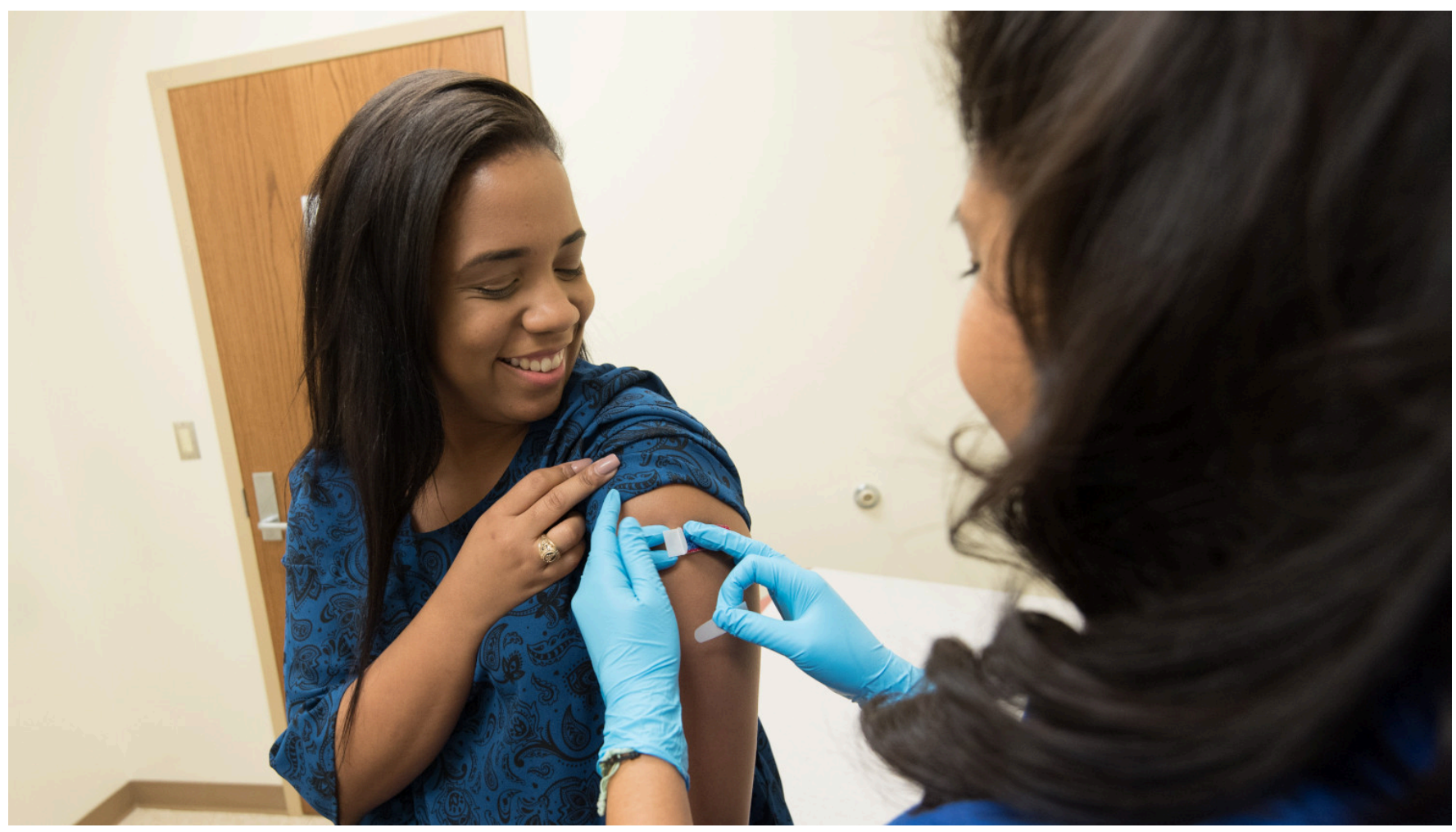


Figur 2. Individuella och samhälleliga överväganden kring vaccination mot covid-19 är exempel på ett område där den didaktiska modellen om riskbegreppet skulle kunna vara användbar. (Bild: CDC/Robert Denty)

Modellen påminner oss om att risk är någonting komplext. De sju termerna i modellen pekar på aspekter som behöver finnas med i en mångsidig och fyllig undervisning som behandlar riskbegreppet. Liksom andra didaktiska modeller kan den användas både före undervisningen - vid planering och design - och efter undervisningen - vid analys och reflektion.

\section{Lärarpanelen}

Robert Andersson är gymnasielärare och undervisar i naturkunskap, biologi och bioteknik på Alléskolan i Hallsberg (Figur 3). I sin undervisning har han främst kommit in på risk genom frågeställningar såsom för- och nackdelar med GMO eller förvaring av radioaktivt kärnavfall. Men även vaccin har varit ett fokus under corona-pandemin, där modellen pekar på viktiga aspekter:

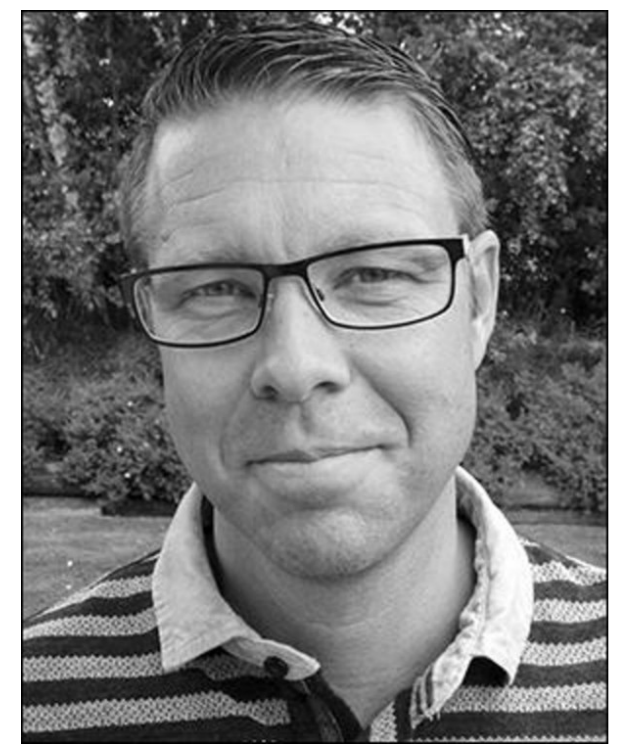

Figur 3. Robert Andersson.

- Precis som modellens begrepp lyfter fram så kan man se ett dualistiskt förhållande mellan det subjektiva och det objektiva, menar Robert, som upplever att det tenderar att bli mer subjektiva resonemang i vaccinfrågan.

Robert har egna erfarenheter av didaktiska modeller (se t.ex. [4]) och rekommenderar användning av dessa som redskap för planering, genomförande och utvärdering för såväl den enskilda läraren som vid samarbete mellan flera lärare.

Han tänker såhär kring användningen av modellen i artikeln:

- I sin enklaste form kan den fungera som en bra ram för att strukturera en lektion där aspekter om risk kommer in. Det kan till exempel börja med att lyfta fram en aktivitet, såsom vaccin, och därefter presentera både kunskaper som vi är mer säkra på och det som är osäkert.

- Beroende på elevernas bakgrund och vad som kommer upp vid till exempel en diskussion kan man komma in på modellens andra aspekter. När det gäller till exempel sannolikhet kan det lyftas antingen i termer av "större" eller "mindre", eller matematiska uttryck (ex. antal vaccinerade jämfört med dokumenterade fall med biverkningar). 
- Om man istället vill fånga värderingar så kan man inleda med att fråga hur eleverna själva tänker kring att vaccinera sig. Då synliggörs att man ofta utgår från sig själv. Att därefter förklara att ett vaccinationsprogram bygger på att en stor andel vaccinerar sig kan då lyfta frågan vidare.

Robert ser också en stor potential i att använda modellen för att lyfta in undervisning om naturvetenskapens karaktär i samband med risk. Inte minst i förhållande till just vaccin, där frågor om källkritik och det rådande kunskapsläget är viktiga aspekter.

\section{Fotnoter}

1. Läs gärna vidare om RiskEdu-projektet här:

https://www.skolfi.se/forskningsfinansiering/finansierade-forskningsprojekt-2017/riskedu-ii/

\section{Referenser}

1. Schenk L, Hamza K, Enghag M, Lundegård I, Arvantis L, Haglund K, Wojcik A. Teaching and discussing about risk: Seven elements of potential significance for science education. International Journal of Science Education. 2019;41(9).

2. Lunde T, Sjöström J. Didaktiska modeller som kärnan i ämnesdidaktik - forskning som eftersträvar en professionsvetenskap för lärare. ATENA Didaktik. 2021;3(1).

3. Bossér U, Sjöström J. Samhällsfrågor i nv-klassrummen - från enkel kontextualisering till fokus på handlingskompetens för global miljörättvisa. ATENA Didaktik. 2020;2(1).

4. Andersson R. Erfarenheter av en didaktisk modell för undervisning om hållbar energi. ATENA Didaktik. 2019;1(1). 